\title{
Directive Speech Acts Performed in Khutbah (Islamic Friday Sermon)
}

\author{
Cipto Wardoyo \\ Adab and Humanities Faculty, UIN Sunan Gunung Djati, Bandung, Indonesia \\ cipto_w@yahoo.com
}

\begin{abstract}
Khutbah is the primary formal occasion for public preaching in the Islamic tradition. Khutbat al-jum'ah or Friday sermon is delivered in the mosque weekly on Friday. The Friday prayer is one of the symbols of Islam, one of the most important aspects of the worship performed on Jumu'ah day is the delivery of the Friday sermon (khutbah). The khutbah originates from the practice of the Islamic prophet, Muhammad, who used to deliver words of exhortation, instruction, or command at gatherings for worship in the mosque. By serving as a means to unite, educate, and build Muslim community, the Friday sermon has been transformed beyond a religious ritual into an important social institution. The content of the $k h u t b a h$ can be viewed as a social commentary on the conditions that confront particular Muslim community. This paper attempted to analyze Friday sermon linguistically on how directive speech acts are performed by preacher. According to Searle directive speech act occurs when the speaker expects the listener to do something. Moreover, Huang (2007) states that directive speech acts can be performed to several types, which are advices, commands, orders, questions and requests. The data of this research were taken from Majlis Ugama Islam Singapura (Islamic Religious Council of Singapore) in the form of written Friday sermons at http://www.officeofthemufti.sg/khutbah.html. This study used qualitative method; the descriptive interpretative technique was used for analyzing the data. The researcher read the written Friday sermon, found the utterances using directive speech acts and explained the phenomena using pragmatic theories.
\end{abstract}

Keywords: Khutbah (Friday Sermon), Directive, Speech Acts, Pragmatics

\section{INTRODUCTION}

In Islamic society, masjid (mosque) is very important because it is not only a place for ritual activities but also a place for seeking knowledge. In prophetic history, Nabawi mosque became formal institution for ritual, seeking knowledge, center of economy and politics, and the place where Prophet Muhammad as the Islamic leader lived. According to prophetic tradition seeking knowledge is an obligation for a Muslim, so every Muslim should venerate seeking knowledge especially that of their religion. Masjid has important role to educate Islamic followers about the concept of Islamic teaching in particular, such as how to perform Islamic rituals, how people live based on God's command, and how to seek happiness based on Islamic concept.
Khutbah is the primary formal occasion for public preaching in the Islamic tradition since the prophetic era in Medina. Friday prayer is an obligation ritual in Islamic teaching for mature male or Muslim. It is the collective prayer for Muslim society as based on Syafi'i scholar Friday prayer should consists of at least 40 people. Khutbah al-jum'ah or Friday sermon is delivered in the mosque weekly on Friday as the series of Friday prayer.

The Friday prayer is one of the symbols of Islam; one of the most important aspects of the worship performed on Jumu'ah day is the delivery of the Friday sermon (khutbah). The khutbah originates from the practice of the Islamic prophet, Muhammad, who used to deliver words of exhortation, instruction, or command at gatherings for worship in the mosque. By serving as a means of uniting, educating, and building Muslim community, the Friday sermon has transformed beyond its original purpose into an important social institution. The content of the khu bah can be viewed as a social commentary on the conditions faced by Muslim community itself.

Speech acts are defined by Yule (1996) as actions performed through utterances; in English they are commonly given more specific labels such as apology, invitation, request or promise. Moreover, there are five classifications of speech acts: representative, expressive, directives, commisive, and declarations.

According to Searle directive speech act occurs when the speaker expects the listener to do something. Huang (2007) states that directive speech acts can be performed to several types of speech, which are advice, commands, orders, questions and requests. Moreover, Leech (1990) describes that directive speech has some attitudes. Firstly, the intention of speaker is that hearer do something, such as in telling, commanding, ordering, and asking. Second, speakers wish the hearer do something, such as in request, beg, and advise. The third, speakers believe that something will be good for hearer, such as in recommendation and suggestion. The third, speakers have willingness for hearer to do something, such as in invitation. 


\section{METHODS}

This paper attempted to analyze Friday sermon linguistically on how directive speech acts are performed by preacher. The data of this research, which are written Friday sermons, were taken from Majlis Ugama Islam Singapura (Islamic Religious Council of Singapore) at http://www.officeofthemufti.sg/khutbah.html. The data were taken from two months of weekly Friday sermon, from April $1^{\text {st }}$ until May $27^{\text {th }}, 2016$. The writer used qualitative method in this paper. According to Cresswell (1994: 2) qualitative is a process of understanding social or human problems in complex building, holistic picture, formed in verbal languages. The descriptive interpretative technique through discourse analysis is used for analyzing the data. Discourse Analysis has a strong focus on studying language and it is often used as an analytic tool by researchers from other disciplines. According to Listosseliti (2010) the most common sources of data for discourse analysis tend to be the accounts drawn from recordings of informal spoken. Discourse analysis is limited by its lack of a formal apparatus by which to conduct such microanalyses, and tends to borrow a particular method from a range of fields such as speech act theory and grammar.

\section{FINDING AND DISCUSSION}

There are 56 data of directive speech acts found in Friday sermons of Majlis Ugama Islam Singapura in two months of weekly Friday sermon from 1st April 2016 until 27th Mei 2016.

\section{1) Invite}

According to Merriam Webster online dictionary (2016) "invite" is defined to ask (someone) to go somewhere or do something, to ask (someone) formally or politely to do something, to request (something) formally or politely. Furthermore, Leech (1990) defines inviting speakers as one who have willingness for hearer to do something. There are 22 data identified with invitation strategy in Friday sermons, using the structure "let us + Verb Infinitive". They are presented as follows:

1. Let us lower ourselves in humility. Seek from Allah s.w.t. a true sense of takwa (Friday Sermon 1 April 2016)

2. So let us learn to be tawadhu', humble and never allow ourselves to feel that we know everything and only our opinions are right (Friday Sermon 1 April 2016)

3. Let us emulate Prophet Musa a.s. in his humility in seeking knowledge (Friday Sermon 1 April 2016)

4. Let us increase our takwa to Allah s.w.t. through our speech, actions and deeds. (Friday Sermon 8 April 2016)

5. Let us increase our taqwa in Allah s.w.t.( Friday Sermon 15 April 2016)
6. Let us renew our commitment to obey all that is commanded by Allah s.w.t. and abstain from what He has prohibited .( Friday Sermon 15 April 2016)

7. Let us thus increase our gratitude towards Allah.( Friday Sermon 15 April 2016)

8. Hence let us take this opportunity to increase our good deeds and acts of devotion to Allah s.w.t.( Friday Sermon 15 April 2016)

9. So let us develop the excitement and fervour to intensify our ibadah and to be in service to those who need us. .( Friday Sermon 15 April 2016)

10. Let us boost our taqwa to Allah s.w.t., renew our resolution to heed all of Allah's commands and abstain from His prohibitions (Friday Sermon 22 April 2016)

11. Let us reflect upon the hadith of Prophet Muhammad s.a.w. which highlights the importance of being humble in performing good deeds (Friday Sermon 22 April 2016)

12. Let us have taqwa in Allah with the highest sense of taqwa by obeying all of His commands and abstaining from His prohibitions (Friday Sermon 6 May 2016)

13. Let us reflect upon ourselves and strengthen our religious practices so that we will be at the forefront in spreading peace and mercy (Friday Sermon 13 May 2016)

14. Let us increase our takwa to Allah and strengthen our relationship with Allah (Friday Sermon 20 May 2016)

15. Let us continue to spend the rest of Syaaban by reflecting upon how we have interacted with other Muslims, including on social media (Friday Sermon 20 May 2016)

16. Let us take advantage of the last few days of Sya'ban to be more diligent in our preparations to welcome Ramadan. (Friday Sermon 27 May 2016)

17. When interacting with others, let us emulate the character of Rasulullah s.a.w who was merciful and brought blessings to the universe. (Friday Sermon 27 May 2016)

18. Let us be a Muslim community that is exemplary in our deeds and actions. (Friday Sermon 27 May 2016)

19. Let us ensure that our speech and actions are gracious and respectful, (Friday Sermon 27 May 2016)

20. Let us make it a personal goal to radiate blessings and mercy to every single person who interacts with us, no matter their religion or race (Friday Sermon 27 May 2016)

21. So let us pray to Allah to make us agents of peace. (Friday Sermon 27 May 2016)

22. Let us come together and reflect upon ourselves in these last few days of Sya'ban (Friday Sermon 27 May 2016) 
There are 2 data of invitation strategy that use negative sentence by employing "let us+ not + infinitive verb" structure:

1. When we receive a blessing, an appreciation or a compliment, let us not forget to recite (hadza min fadhli Robbi) or (masya Allah la quwwata illa billah). ( Friday Sermon 15 April 2016)

2. Let us not allow for bad manners and demean our to hide the beauty of the true teachings of Islam. (Friday Sermon 27 May 2016)

\section{2) Order}

Order as imperative sentence uses specific form that the verbs is always at the beginning of the sentence. According to Merriam Webster dictionary (2016) order is a statement made by a person with authority that tells someone to do something, an instruction or direction that must be obeyed. In addition, Kaufmann (2012) states that "order" expresses simple necessity to what speaker orders. There are 7 data of order in Friday sermon, shown as follows:

1. Ask for strength from the Almighty, so that we can fulfill all of His commands and abstain from His prohibitions (Friday Sermon 1 April 2016)

2. Instil in our hearts the intention to follow the footsteps of Prophet Musa a.s. in diligently collecting the gems of knowledge from others who are more pious and learned(Friday Sermon 1 April 2016)

3. Remember what our beloved messenger Prophet Muhammad s.a.w. had once said: "No one who has the weight of a seed of arrogance in his heart will enter Paradise." (Friday Sermon 8 April 2016)

4. Think about our actions toward Allah s.w.t. as well as our actions toward others; (Friday Sermon 8 April 2016)

5. Watch our words on social media, (Friday Sermon 8 April 2016)

6. Seek the advice and honest evaluation from those closest to us. (Friday Sermon 8 April 2016)

7. Seek from Allah that he places the key to peace in our hands, and in our future generations (Friday Sermon 27 May 2016)

\section{3) Request}

According to Leech (1990) request means that speakers wish the hearers do something. In addition, Merriam Webster states that request is an act of politely or formally asking for something. It means that request uses strategy of politeness to ask the hearers do something. There is only a datum of request in the Friday sermons:

This week, I would like to ask us to reflect on how our daily ritual acts, (Friday Sermon15 April 2016)

The utterance above uses structure "would like + to ask"; it is a polite way to ask someone to do something.

\section{4) Prohibition}

According to Merriam-Webster dictionary (2016) prohibitions is the act of not allowing something to be used or done or a law or order that stops something from being used or done. Moreover, Kaufmann (2012) states that prohibition is negated imperatives; it is expressed via negation of its complement under contextual constellations where the ordering source is set to the speaker's commands. There are 6 data using prohibition strategies in Friday sermon, as shown in the following sentences:

1. Jemaah, never forget that it is Allah s.w.t. who is the Owner of everything in the heavens and the earth, and the Owner of all the knowledge in our hearts and minds (Friday Sermon 1 April 2016)

2. Do not feel arrogant of the little that we know, even if we feel that we have known a lot (Friday Sermon 1 April 2016)

3. Avoid feeling that our knowledge is suffificent and we do not need to learn from others (Friday Sermon 1 April 2016)

4. Avoid all that He has prohibited upon us, to the best of our abilities (Friday Sermon 8 April 2016)

5. Do not forget to make istighfar and seek Allah's forgiveness. (Friday Sermon 29 April 2016)

6. We cannot allow any war, enmity and conflicts to colour our thoughts as to how we view people of other faiths, (Friday Sermon 13 May 2016)

\section{5) Suggestion}

According to Merriam Webster dictionary (2016), suggestion is an idea about what someone should do or how someone should behave. Moreover, Leech (1990) states that suggestion is the condition that speakers believe will be good for hearer. The modal "should" is commonly used to make suggestion and recommendations or to give advice. There are 11 data using suggestion strategies in the Friday sermons comprising of 8 data using modal "should", 2 data using "need", and a datum using modal "must" as a strong suggestion:

1. Blessed Jemaah, there are many aspects of humility that should be observed by every believer (Friday Sermon 1 April 2016)

2. We should never judge others based on what we see (Friday Sermon 22 April 2016)

3. We should never forget to put our trust and dependence on Allah s.w.t. by making supplication (doa) (Friday Sermon 29 April 2016)

4. They should remember and abide by Allah's reminders. (Friday Sermon 13 May 2016)

5. We should not make differences of religious beliefs as a hurdle for us to live harmoniously together (Friday Sermon 13 May 2016) 
6. This should be reflected in our speech and action. (Friday Sermon 13 May 2016)

7. We should also exude the values of mercy in our daily lives. (Friday Sermon 13 May 2016)

8. We should watch our words and actions, and ensure that we do not contribute to disputes and divisions among Muslims (Friday Sermon 20 May 2016)

9. We need to self-reflect or do muhasabah (Friday Sermon 27 May 2016)

10. We need to be a person who is always grateful to the goodness extended to us (Friday Sermon15 April 2016)

11. We must always spend time reflecting on ourselves and reflect upon our weaknesses and mistakes. (Friday Sermon 29 April 2016)

\section{6) Remind}

According to Merriam Webster dictionary (2016) the word "remind" means to make (someone) think about something again, it is the way to cause (someone) to remember something. There are four strategies of directive speech acts using reminding strategy as shown in the sentences below:

1. All of these which I have mentioned above serve to remind us to not be boastful, and to remember that all blessings and praises belong to Allah s.w.t. who is ArRazzaaq (Friday Sermon15 April 2016)

2. This is to remind us to not be forgetful of their sacrifices and affection towards us (Friday Sermon15 April 2016)

3. We are also taught to humble ourselves to our parents. (Friday Sermon15 April 2016)

4. In facing differences of opinions among Muslims (intra-faith), what is required is a high level of maturity and not strong displays of emotions; mutual love and not hatred

(Friday Sermon 20 May 2016)

\section{CONCLUSION}

Based on finding and discussion above, it can be concluded that Friday sermons use various strategies of directive speech acts. From the findings, it was found that the preacher in Friday sermons used inviting strategies more dominantly; it is in 24 data. The second dominant strategy is suggestion, which is identified in 11 data. The third dominant strategy is order, with 7 data. The fourth dominant was prohibition strategy in 5 data. The strategy of remind was in 4 data and strategy of request was only identified once.

\section{REFERENCES}

Cresswell, John W. 1994. Research Design: Qualitative and Quantitative Approaches. London: Sage

Huang, Yan. 2007. Pragmatics. London: Oxford University Press.
Kaufmann, Magdalena. 2012. Interpreting Imperatives. Germany: Springer

Leech, Geoffrey N.1990. Principle of Pragmatics. USA: Longman Group Limited

Yule, George. 1996. Pragmatics. Oxford: Oxford University Press

http://www.officeofthemufti.sg/khutbah.html

http://www.merriam-webster.com/dictionary 